\title{
Taxon-specific growth and loss rates for dominant phytoplankton populations from the northern Gulf of Mexico
}

\author{
Gary L. Fahnenstiel ${ }^{1}$, Michael J. McCormick ${ }^{2}$, Gregory A. Lang ${ }^{2}$, Donald G. Redalje ${ }^{3}$, \\ Steven E. Lohrenz ${ }^{3}$, Michael Markowitz ${ }^{2}$, Bruce Wagoner ${ }^{2}$, Hunter J. Carrick ${ }^{2, *}$ \\ ${ }^{1}$ Great Lakes Environmental Research Lab/NOAA, 1431 Beach St., Muskegon, Michigan 49441, USA \\ ${ }^{2}$ Great Lakes Environmental Research Lab/NOAA, 2205 Commonwealth Blvd, Ann Arbor, Michigan 48105, USA \\ ${ }^{3}$ Center for Marine Science, Univ. Southern Mississippi, Stennis Space Center, Mississippi 39529, USA
}

\begin{abstract}
Taxon-specific growth and sedimentation rates of dominant phytoplankton were measured during 2 cruises (summer 1990 and spring 1991) in the northern Gulf of Mexico as part of the NOAA Nutrient-Enhanced Coastal Ocean Productivity (NECOP) program. Microzooplankton grazing rates also were measured during the summer cruise. During each of the cruises, a series of stations from the Mississippi River mouth to the hypoxia region (located ca 50 to $100 \mathrm{~km}$ west) were sampled to examine variability of growth and loss processes along a strong environmental gradient. Significant taxa- and group-specific differences were noted for both growth and loss rates. Growth rates ranged from $<0.1$ to $3.0 \mathrm{~d}^{-1}$ with highest rates in the plume region during the summer cruise, where surface rates were close to or exceeded previous $\mu_{\max }$ values for several taxa. For all taxa, growth rates were lower in the hypoxia region (mean $=0.5 \mathrm{~d}^{-1}$ ) than in the plume region (mean $=1.1 \mathrm{~d}^{-1}$ ); soluble nitrogen concentrations explained over $50 \%$ of the variability in growth rates. Diatom growth rates were similar to non-diatoms in the plume region, but were significantly lower in the hypoxia region, which suggests that silica limitation may exist in this region. The fate of phytoplankton appeared to be controlled by size and by the degree of silicification. Significant microzooplankton grazing loss rates were noted only for small taxa $(<20 \mu \mathrm{m})$. For microflagellates, microzooplankton grazing rates averaged $82 \%$ (range 42 to $214 \%$ ) of the growth rate; sedimentation rates were always $<1 \%$ of the growth rate. Sedimentation was an important loss for several diatoms, with significant taxon-specific and seasonal differences noted. Large colonial diatoms, such as Skeletonema costatum and Thalassiosira rotula, exhibited the highest sedimentation rates in the plume region during the spring cruise $\left(0.2\right.$ to $\left.1.0 \mathrm{~d}^{-1}\right)$, whereas the lowest rates $\left(<0.01 \mathrm{~d}^{-1}\right)$ were noted for Rhizosolenia fragilissima and Ceratulina pelagica in the hypoxia region during the summer cruise. Our results suggest that in the northern Gulf of Mexico, phytoplankton rate processes proceed very rapidly, with growth rates primarily controlled by the supply of nitrogen via the Mississippi River and the fate controlled primarily by size and density (silicification).
\end{abstract}

KEY WORDS: Phytoplankton - Growth rates · Loss rates · Gulf of Mexico

\section{INTRODUCTION}

Phytoplankton abundance is controlled by a combination of growth and loss processes, and a large amount of information exists on the abundance and distribution

\footnotetext{
- Present address: Dept of Biology, San Francisco State University, San Francisco, California 94132, USA
}

of phytoplankton taxa in a variety of freshwater and marine systems (for reviews see Guillard \& Kilham 1977, Raymont 1980, Smayda 1980). However, very few measurements have been made of species growth and loss processes (Knoechel \& Kalff 1978, Crumpton \& Wetzel 1982, Landry et al. 1984, Campbell \& Carpenter 1986). Phytoplankton growth and loss processes are usually measured at the community level using bulk techniques, such as chlorophyll or carbon analysis, which 
provide no taxonomic resolution. While this community information is useful for examining general patterns and trends, it often lacks the discrimination needed to elucidate the factors controlling phytoplankton population dynamics. Even though little information exists at the species level, phytoplankton ecologists generally recognize the importance of species processes and composition in determining seasonal succession and even ecosystem structure and function (Crumpton \& Wetzel 1982, Wood \& Leatham 1992). Recently, Carpenter et al. (1993), in a review of species dynamics and their relationship to global environmental change, concluded that individual species have substantial effects on ecosystem processes and serve as optimal indicators of impending ecosystem change. The lack of information at the species level for phytoplankton is primarily due to logistical barriers associated with the measurements (Crumpton \& Wetzel 1982).

Despite the limited information on species- or taxonspecific rates for phytoplankton, particularly for nanoplankton-sized organisms, the existing data have provided insights into the relative importance of growth and loss processes in seasonal succession of phytoplankton populations. In a rare study where growth and loss processes were measured for individual taxa during summer stratification in a small lake, Crumpton \& Wetzel (1982) concluded that loss processes, such as sedimentation and zooplankton grazing, were more important than interspecific competition and growth rate differentials in actually controlling the seasonal succession of phytoplankton. Similar conclusions were reached by 2 earlier studies in which species-specific rates of production and growth were measured and loss rates were calculated (Knoechel \& Kalff 1975, 1978). Taken together, the results from these studies contradicted the arguments that (1) phytoplankton population dynamics and community structure were controlled by interspecific competition and growth differentials, and (2) that mortality by sedimentation and grazing were generally insignificant (Crumpton \& Wetzel 1982). In a review of phytoplankton dynamics in lakes, Kalff \& Knoechel (1978) suggested that more emphasis should be placed on loss processes. In the marine environment, however, very little information exists on the importance of taxon-specific growth and loss processes for nanoplanktonic-sized organisms.

The outfall region of the Mississippi River is a particularly good region to examine taxon-specific processes due to the large environmental variability found in this region and the strong river signal. The Mississippi River is the sixth largest river system in the world; its tributaries drain approximately $40 \%$ of the continental United States (Moody 1967). Anthropogenic nutrients from the Mississippi River likely enhance primary pro- ductivity and other processes in the northern Gulf of Mexico (Riley 1937, Thomas \& Simmons 1960, Sklar \& Turner 1981, Lohrenz et al. 1990, Turner \& Rabalais 1991). It was because of this concern that the NOAA Nutrient-Enhanced Coastal Ocean Productivity (NE$\mathrm{COP}$ ) program was initiated to quantitatively determine the impact of Mississippi River nutrient loading on primary productivity and fate of fixed carbon in the northern Gulf of Mexico. Our goals were to examine taxon-specific processes for dominant phytoplankton and to determine both the extent of nutrient controls and the fate of phytoplankton.

\section{METHODS}

Sampling was conducted on 2 cruises aboard the RV 'Baldridge', 1 during summer (July/August 1990) and 1 during spring (March 1991). On the summer cruise, 3 stations were sampled on a transect from the river mouth at Southwest Pass to the inner part of the hypoxia region (Fig. 1). The first 2 stations (Stns 1 and 2), which will be referred to as plume stations, were sampled on July 22 and July 25; the third station (Stn 3 ), which will be referred to as a hypoxia station, was sampled on August 2-3. On the spring cruise, 4 stations were sampled. Two of these stations, sampled on March 6 and 8, were located in the plume region (Fig. 1, Stns 5 and 6) and one station, sampled on March 12, was located in the hypoxia region (Stn 7). One additional station was sampled east of the Mississippi River Delta on March 5 (Stn 4).

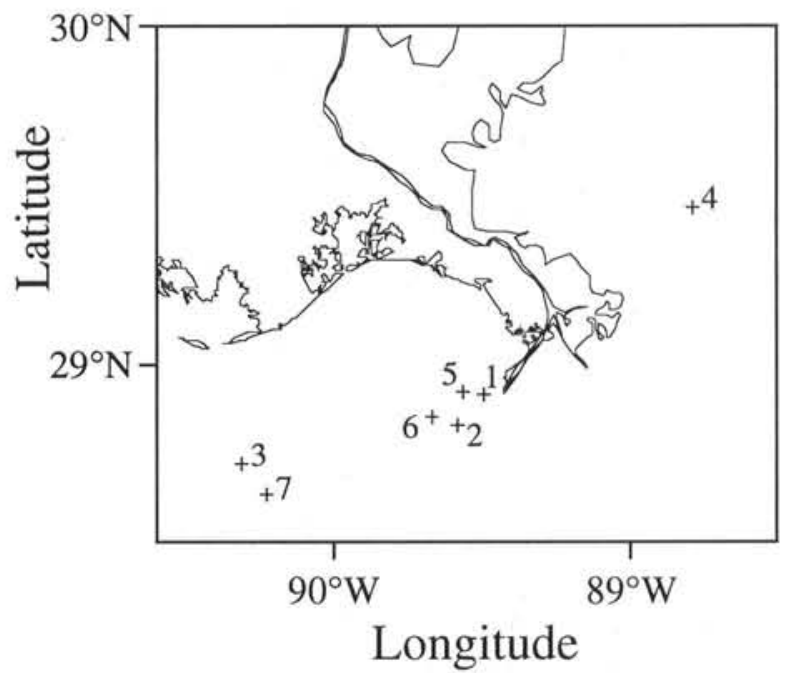

Fig. 1. Location of sampling stations $(+)$ during the July/ August 1990 and March 1991 NECOP cruises in the Gulf of Mexico. During the 1990 cruise 2 plume stations ( 1 and 2 ) and 1 hypoxia station (3) were sampled. During the 1991 cruise 2 plume stations (5 and 6), 1 hypoxia station (7), and 1 station east of river mouth (4) were sampled 
All water samples were collected early in the morning, generally before dawn, with modified acid-washed Niskin bottles. In order to avoid chemical contamination, all rubber parts of the Niskin bottle (o-rings, closure tubing, etc.) were replaced with silicone parts. Collected water was immediately transferred to 201 polyethylene carboys for sample processing.

A Sea-Cat CTD with transmissometer and PAR sensor was used to measure vertical profiles of temperature, conductivity, PAR, and percent light transmission. Inorganic carbon concentrations were determined by infrared absorption spectroscopy.

The ${ }^{14} \mathrm{C}$ technique was used for estimating carbon uptake. Briefly, 11 polycarbonate bottles were gently filled with raw water, inoculated with $\mathrm{NaH}^{14} \mathrm{CO}_{3}$, and incubated in a deck-simulated in situ incubator (Lohrenz et al. 1992). The light levels in the incubators $(50,25,12,6,3$ or $1 \%$ of surface irradiance) were arranged to correspond to in situ irradiances at the sampling depths. Incubations were initiated and terminated at dawn (24 h incubation). Following incubation, aliquots from the sample bottles were preserved with Lugol's solution, immediately filtered onto $1.22 \mu \mathrm{m}$ Millipore filters, and transferred onto gelatin-coated slides. These gelatin-coated slides were then frozen for track autoradiographic analysis.

Track autoradiography was used to estimate the specific activity (dpm cell ${ }^{-1}$ ) of individual cells (Carney \& Fahnenstiel 1987). Gelatin-coated slides were dipped in filtered subbing solution (Knoechel \& Kalff 1976) and then dipped in NTB-3 photographic emulsion at $29^{\circ} \mathrm{C}$. Slides were allowed to dry and then were developed as described in Carney \& Fahnenstiel (1987). Tracks per cell were enumerated and activity (dpm cell ${ }^{-1}$ ) was calculated (Knoechel \& Kalff 1976). A minimum of 100 cells were enumerated for most taxa at each depth; we therefore confined our cell-specific activity to only the most abundant taxa on each sampling date. For each sample, the taxa analyzed for autoradiography represented 60 to $90 \%$ of total phytoplankton based on counts of the autoradiography slides. Because some delicate taxa (i.e. flagellates) and picoplankton were likely missed and/or damaged beyond recognition with our autoradiography procedures and because large rare species (i.e large dinoflagellates) were not counted, we cannot assume that our counts are representative of the entire phytoplankton community. Also, because we analyzed only a part of the entire phytoplankton community, our taxon-specific rates cannot be used to calculate meaningful community rates.

We estimated taxon-specific growth rates from ${ }^{14} \mathrm{C}$-autoradiography experiments by making simple assumptions about cell growth. Because we did not actually measure growth or division, and because our model assumes carbon uptake and division are continuous, our ${ }^{14} \mathrm{C}$-based growth estimates should be regarded as first-order estimates of actual phytoplankton growth. The approach we used has been described in various ways throughout the literature (e.g. Welschmeyer \& Lorenzen 1984, Li 1984, and Li \& Goldman 1986). Let $C^{*}$ be the specific activity of cellular ${ }^{14} \mathrm{C}\left(\mathrm{dpm}\right.$ cell $\left.{ }^{-1}\right), U$ be the uptake rate of $\mathrm{C}$ $\left(C\right.$ cell $\left.{ }^{-1} \mathrm{~d}^{-1}\right), t$ be the time (d), $\mu$ be growth rate $\left(\mathrm{d}^{-1}\right)$, and $\alpha$ be the isotope discrimination factor; then the instantaneous time rate of change of cellular ${ }^{14} \mathrm{C}$ is

$$
\frac{\mathrm{d} C^{*}}{\mathrm{~d} t}=\alpha U-\mu C^{*}
$$

Note that when growth is referenced to a cellular framework, it represents a loss term reflecting the transfer of carbon due to cell division. At time $t=0$, the initial value of $C^{*}$ is 0 . The solution of Eq. (1) is

$$
C^{*}=\frac{\alpha U}{\mu}\left(1-\mathrm{e}^{-\mu t}\right)
$$

Eq. (2) is further simplified by recognizing that

$$
C_{\text {asy }}=\frac{\alpha U}{\mu}
$$

where $C_{\text {asy }}$ is the asymptotic activity of $C^{*}$; moreover

$$
C_{\text {asy }}=C_{\mathrm{m}} C_{\mathrm{c}}
$$

where $C_{\mathrm{m}}$ is the specific activity of the inorganic medium, which for all practical purposes remains approximately constant throughout the experiment, and $C_{\mathrm{c}}$ is the cell carbon content. Thus $C^{*}$ can be related to $\mu$ at any time $t$ by parameters that can be directly measured $\left(C^{*}, t\right.$, and $\left.C_{\mathrm{m}}\right)$ or approximated through volume-based estimates of cell carbon $\left(C_{\mathrm{c}}\right)$.

$$
C^{*}=C_{\text {asy }}\left(1-\mathrm{e}^{-\mu t}\right)
$$

Finally, the growth rate $\mu$ is calculated from Eq. (5) and

$$
\mu=-\frac{1}{\Delta t} \ln \frac{C_{\text {asy }}-C^{*}}{C_{\text {asy }}}
$$

where $\Delta t$ is the incubation time interval corresponding to $C^{*}$. All of the ${ }^{14} \mathrm{C}$ growth rates reported herein were calculated according to Eq. (6). Depth-specific growth rates were integrated throughout the upper water using a modified version of the model described by Fahnenstiel et al. (1988) by prescribing light variations from incident and underwater irradiance to growth rate versus depth profiles. The highest growth rate (at 50 or $25 \% I_{0}$ ) was assumed to be the light-saturated rate and growth rates were extrapolated to zero at zero irradiance.

The dilution method also provided another independent estimate of phytoplankton growth as well as 
an estimate of the grazing loss rate by the microzooplankton community (Landry \& Hassett 1982). In these experiments, microzooplankton abundances were manipulated through a series of dilutions with filtered seawater, and changes in abundances of phytoplankton populations were noted. These bottle dilutions were performed by mixing appropriate volumes of screened seawater $(<200 \mu \mathrm{m})$ with filtered seawater (Whatman GF/F filtered water) in 21 polycarbonate bottles. Five treatments were used for each experiment, $100 \%$ screened water (SW), $86 \%$ SW, $64 \%$ SW, $42 \%$ SW, and $21 \%$ SW. Near-surface water ( 0 to $1 \mathrm{~m}$ ) was used for all dilution experiments. Bottles were incubated for $24 \mathrm{~h}$ in a temperature-controlled deck incubator. Because increasing bottle dilution alleviates grazing pressure, the slope of phytoplankton growth rate (dependent variable) versus dilution treatments (independent variable) is an estimate of the microzooplankton grazing loss rate; the intercept is an estimate of the phytoplankton growth rate. Complete dilution experiments were performed only on the summer 1990 cruise either simultaneously with ${ }^{14} \mathrm{C}$ experiments (July 25) or $1 \mathrm{~d}$ later (August 3). During the spring 1991 cruise, dilution treatments of $5 \%$ raw water were used to estimate phytoplankton growth rates on the same day as the ${ }^{14} \mathrm{C}$ experiments.

Phytoplankton sedimentation rates were determined from enumeration of a preserved phytoplankton sample collected from a free-floating Multitrap design sediment trap (Knauer et al. 1979, 1990). These traps were deployed in the plume region for $2 \mathrm{~d}$ at $15 \mathrm{~m}$ on July 25 and for $1 \mathrm{~d}$ at $15 \mathrm{~m}$ on March 7. Sediment traps were also deployed in the hypoxia region for $1 \mathrm{~d}$ at $15 \mathrm{~m}$ on August 2 and for $2 \mathrm{~d}$ at $20 \mathrm{~m}$ on March 11 . Sedimentation loss rates for individual taxa were calculated from

$$
L=\frac{1}{t} \ln \left(1+\frac{F}{C Z}\right)
$$

where $L$ is the loss rates $\left(\mathrm{d}^{-1}\right), t$ is time $(\mathrm{d}), F$ is the cellular flux rate from trap sample (cells $\mathrm{m}^{-2} \mathrm{~d}^{-1}$ ), C is the average cell concentration in water column above trap (cells $\mathrm{m}^{-3}$ ), and $Z$ is the depth of trap (m).

In all cases, phytoplankton samples from dilution experiments and sediment trap deployments were preserved with Lugol's solution. These samples were then stored in amber vials until phytoplankton preparations were made. These phytoplankton samples were then filtered onto slides and cleared (Dozier \& Richerson 1975). Dominant taxa, the same ones as for autoradiography experiments, were enumerated under low magnification (200 to $300 \times$ ) and high magnification (600 to $1200 \times$ ). For dilution experiments, the volume filtered ranged from 2 to $60 \mathrm{ml}$ depending on the concentration of phytoplankton. Phytoplankton volumes were estimated by determining the average cell dimensions from a minimum of 50 randomly chosen individuals of each taxon from each sampling date. The average dimensions were then applied to the geometric configuration which best approximated the shape of the taxon (e.g. spheres, prolate spheroids). These cell volumes were then converted to carbon concentrations using the conversions of Strathman (1967) and Verity et al. (1992).

\section{RESULTS}

\section{Ambient conditions}

During both the summer and spring cruises, environmental conditions in the study region suggest that we sampled along the plume/shelf gradient (Fig. 1). During the summer 1990 cruise, the surface mixed layer was relatively shallow $(<4 \mathrm{~m})$ at Stns 1 and 2 . Surface salinity, nitrate, silicate, and temperature values were approximately 15 to $18 \mathrm{ppt},>25 \mu \mathrm{mol} \mathrm{l}^{-1}$, $>15 \mu \mathrm{mol} \mathrm{l}^{-1}$, and 29 to $30^{\circ} \mathrm{C}$, respectively. Conversely, Stn 3 was located in the hypoxia region of the inner shelf where environmental conditions were markedly different from those reported for Stns 1 and 2. The surface mixed layer was approximately $5 \mathrm{~m}$; salinity, nitrate, silicate and temperature values were $26 \mathrm{ppt}, 2 \mu \mathrm{mol} \mathrm{l}^{-1}$, $0.4 \mu \mathrm{mol} \mathrm{l}^{-1}$, and $31^{\circ} \mathrm{C}$, respectively.

Similar plume/hypoxia stations were sampled in the spring 1991 cruise along with an additional station east of the Mississippi River Delta (Stn 4). Conditions at this station were somewhat intermediate of those of the other plume (Stns 5 and 6 ) and hypoxia stations ( $\operatorname{Stn} 7$ ). The surface mixed layer extended to approximately $13 \mathrm{~m}$; surface salinity, nitrate, silicate, and temperature values were approximately $30 \mathrm{ppt}, 5 \mu \mathrm{mol} \mathrm{l}^{-1}, 2 \mu \mathrm{mol}$ $1^{-1}$, and $16^{\circ} \mathrm{C}$, respectively. Stns 5 and 6 were located in the plume region and exhibited relatively similar salinity, nitrate, and temperature values, 21 to $25 \mathrm{ppt}$, $>9 \mu \mathrm{mol} \mathrm{l}^{-1}$ and $17^{\circ} \mathrm{C}$, respectively. The surface mixed layer at these 2 plume stations was approximately 6 to $10 \mathrm{~m}$. Silicate values at these 2 stations were different with higher values at Stn $5\left(4 \mu \mathrm{mol} \mathrm{l}^{-1}\right)$ and barely detectable values at Stn $6\left(<0.4 \mu \mathrm{mol} \mathrm{l^{-1 }}\right)$. At the hypoxia station (Stn 7) salinity values in the surface mixed layer, which extended to approximately 20 to $25 \mathrm{~m}$, were higher (35 ppt); all nutrient values were at or below the detection level $\left(0.4 \mu \mathrm{mol}^{-1}\right)$.

\section{Growth rates}

\footnotetext{
${ }^{14} \mathrm{C}$-based growth rates were determined for 17 dif-
} ferent taxa with diatoms representing over half of 
Table 1. Taxa for which growth and/or loss rates were measured

\section{Diatoms}

Ceratulina pelagica (Cleve) Hendey

Chaetoceros spp.

Cyclotella caspia Grunow

Cyclotella striata (Kutzing) Grunow

Ditylum brightwellii (West) Grunow

Nitzschia pungens Grunow

Rhizosolenia fragilissima Bergon

Skeletonema costatum (Greville) Cleve

Thalassiosira rotula Meunier

\section{Non-diatoms}

Chrysochromulina spp.

Gymnodinium sp.

Katodinium rotundatum (Lohmann) Fott

Ochromonas minima sp. nov.

Ochromonas spp.

Pseudopedinella sp.

Rhodomonas lacustris (Pascher \& Ruttner) Javornicky

Rhodomonas sp.

these; the other taxa were flagellated forms representing a variety of groups (i.e. Cryptophytes, Dinophytes, Haptophytes, etc.; Table 1). Because these ${ }^{14} \mathrm{C}$-growth rates are not actual measurements of growth, we compared our estimates to those from dilution experiments which are based on actual changes in abundance and are useful for evaluating the accuracy of ${ }^{14} \mathrm{C}$-based estimates. It should be noted that dilution estimates are also subject to possible artifacts and are not estimates of actual cellular division.

Overall, ${ }^{14} \mathrm{C}$-based growth rate estimates were not significantly different from dilution estimates (Fig. 2; paired $t$-test, $t=0.15, \mathrm{p}=0.88, \mathrm{n}=37$ ); however, differences were noted for taxonomic groups. For diatoms, dilution growth rates (mean $=0.8 \mathrm{~d}^{-1}$ ) were significantly higher than ${ }^{14} \mathrm{C}$-based rates $\left(\right.$ mean $=0.6 \mathrm{~d}^{-1}$,

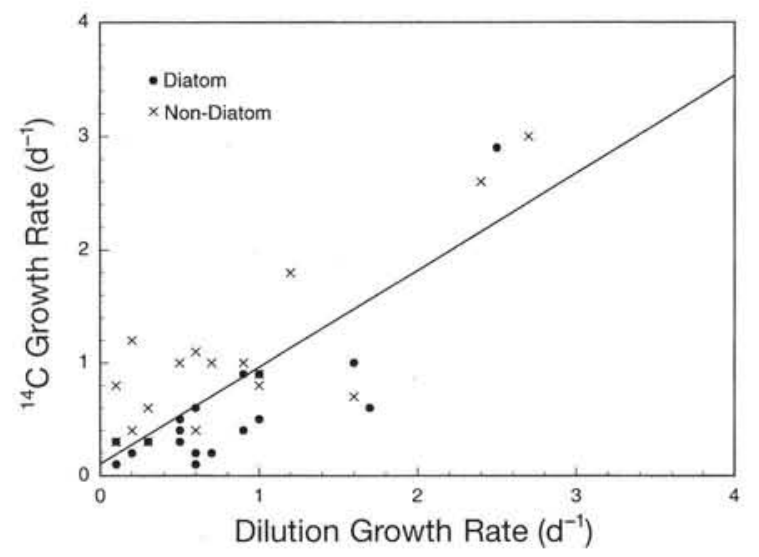

Fig. 2. Surface ${ }^{14} \mathrm{C}$-based growth rates and dilution growth rates for diatoms and non-diatoms. Regression line is plotted $\left(y=0.86 x+0.1, R^{2}=0.66, p<0.001, n=37\right)$ paired $t$-test, $t=2.6, \mathrm{p}=0.02, \mathrm{n}=18$ ). For non-diatoms (flagellated cells), ${ }^{14} \mathrm{C}$-based estimates (mean $=1.0 \mathrm{~d}^{-1}$ ) were slightly higher than dilution rates (mean $=0.8 \mathrm{~d}^{-1}$ ), but these differences were not significant (paired $t$-test, $t=1.9, \mathrm{p}=0.07, \mathrm{n}=19$ ). Despite the differences between techniques for diatoms, we will consider ${ }^{14} \mathrm{C}$ estimates to be accurate, because the differences between techniques ( 20 to $25 \%$ ) are small relative to the range of values observed, 0.1 to $3.0 \mathrm{~d}^{-1}$.

In almost all cases, maximal growth rates were found for near-surface samples, and rates decreased with depth (Fig. 3). In the plume region, growth rates at mid-depths (3 to $4 \mathrm{~m}$, approximately $12 \%$ of surface irradiance) were $75 \%$ of surface $(0.5$ to $1 \mathrm{~m})$ rates, while growth rates near the bottom of the euphotic zone ( $7 \mathrm{~m}$, approximately $3 \%$ of surface irradiance) averaged $22 \%$ of surface values. In the hypoxia region, growth rates at mid-depths (3 to $10 \mathrm{~m}$, ca $12 \%$ of surface irradiance) were $77 \%$ of surface $(1 \mathrm{~m})$ values, and rates near the bottom of the euphotic zone (5 to $18 \mathrm{~m}$, ca $3 \%$ of surface irradiance) averaged $9 \%$ of surface values.

Near-surface growth rates ranged from 0.1 to $3.0 \mathrm{~d}^{-1}$ with highest values found in the plume region (Table 2). For all species, growth rates from the plume region (mean $=1.1 \mathrm{~d}^{-1}$ ) were significantly higher than rates from the hypoxia region (mean $=0.5 \mathrm{~d}^{-1}, t$-test, $t=2.9, \mathrm{p}<0.01$ ). Although non-diatom growth rates appeared to be higher than diatom growth rates, the means were not significantly different (mean diatom $=$ $0.7 \mathrm{~d}^{-1}$, mean non-diatom $=1.0 \mathrm{~d}^{-1}, t$-test, $t=1.7$, $\mathrm{p}=0.09$ ). In the plume region, diatom and non-diatom growth rates were very similar (mean diatom $=0.9 \mathrm{~d}^{-1}$, mean non-diatom $=1.2 \mathrm{~d}^{-1}, t=0.9, \mathrm{p}=0.37$ ); however, in the hypoxia region, diatom growth rates were significantly lower than non-diatom rates (mean diatom $=0.3 \mathrm{~d}^{-1}$, mean non-diatom $\left.=0.7 \mathrm{~d}^{-1}, t=3.6, \mathrm{p}<0.01\right)$.

Despite limited data, we examined the relationships between several environmental variables, soluble nitrogen (nitrate+nitrite+ammonium), silicate, temperature, and salinity, and growth rates of both diatoms and non-diatoms. Significant relationships between all examined environmental variables and growth rates were noted $(\mathrm{p}<0.01)$. The best relationships, in terms of explaining the most variability in growth rates, were found for nitrogen, silicate, and salinity ( $\mathrm{p}<0.001$ ). Overall, significant relationships were noted between nitrogen concentration and growth rate $(y=0.042 x+$ $0.311, \mathrm{R}^{2}=0.59, \mathrm{p}<0.001, \mathrm{n}=43$ ) and between silicate concentration and growth rate $\left(y=0.068 x+0.49, \mathrm{R}^{2}=\right.$ $0.54, \mathrm{p}<0.001, \mathrm{n}=43$ ). Interestingly, a very significant relationship was also noted for salinity and growth rate $\left(y=-0.062 x+2.35, \mathrm{R}^{2}=0.40, \mathrm{p}<0.001, \mathrm{n}=43\right)$. When the same relationships were examined for both diatoms and non-diatoms individually, better relation- 

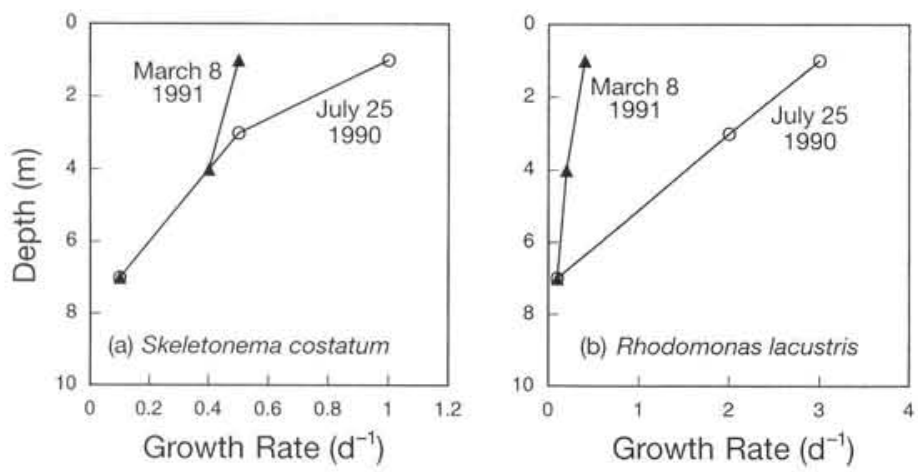

Fig. 3. Growth rates vs depth for (a) a diatom, Skeletonema costatum, and (b) a microflagellate, Rhodomonas lacustris, on July 25, 1990, and March 8, 1991 ships (in terms of explaining the variability in growth rate) were found for non-diatoms than for diatoms for all independent variables including silicate.

\section{Loss rates}

Grazing by microzooplankton $(<200 \mu \mathrm{m})$ was an important loss for phytoplankton populations in the near surface region during the July/August 1990 cruise (Table 2), Unfortunately, samples from microzooplankton grazing experiments were not collected or analyzed from the March 1991 cruise. In the summer,

Table 2. Growth and loss rates $\left(\mathrm{d}^{-1}\right)$ for selected dominant taxa. Microzooplankton (microzoo.) grazing loss rates are compared to ${ }^{14} \mathrm{C}$ and dilution growth rates for surface samples $\left(1\right.$ or $2 \mathrm{~m}$ ). Sedimentation (sed.) loss rates are compared to integrated ${ }^{14} \mathrm{C}$ growth rates for the 0 to 15 or 0 to $20 \mathrm{~m}$ region. Error estimates are $95 \%$ confidence intervals. "Surface rates not significantly different from zero $(\mathrm{p}=0.05)$

\begin{tabular}{|c|c|c|c|c|c|c|c|c|}
\hline \multirow[t]{2}{*}{ Taxa } & \multirow[t]{2}{*}{ Date } & \multicolumn{4}{|c|}{ Surface rates } & \multicolumn{3}{|c|}{ Integrated rates } \\
\hline & & $\begin{array}{l}\text { Depth } \\
\text { (m) }\end{array}$ & $\begin{array}{l}{ }^{14} \mathrm{C} \\
\text { growth }\end{array}$ & $\begin{array}{l}\text { Dilution } \\
\text { growth }\end{array}$ & $\begin{array}{c}\text { Microzoo. } \\
\text { grazing }\end{array}$ & $\begin{array}{l}\text { Depth } \\
\text { (m) }\end{array}$ & $\begin{array}{l}{ }^{14} \mathrm{C} \\
\text { growth }\end{array}$ & Sed. rate \\
\hline \multirow[t]{3}{*}{ Skeletonema costatum } & Jul 25, 1990 & 1 & $1.0 \pm 0.2$ & $1.6 \pm 0.4$ & $-0.4 \pm 0.6^{*}$ & $0-15$ & 0.3 & -0.3 \\
\hline & Mar 8, 1991 & 1 & $0.5 \pm 0.1$ & $1.0 \pm 0.2$ & - & $0-15$ & 0.2 & -0.6 \\
\hline & Mar 12, 1991 & 2 & $0.3 \pm 0.1$ & $0.5 \pm 0.1$ & - & $0-20$ & 0.3 & -0.2 \\
\hline \multirow[t]{2}{*}{ Nitzschia pungens } & Aug 2, 1990 & 1 & $0.2 \pm 0.1$ & $0.7 \pm 0.6$ & $-0.3 \pm 1.0^{\circ}$ & $0-15$ & 0.1 & $<-0.001$ \\
\hline & Mar 12, 1991 & 2 & $0.5 \pm 0.1$ & - & - & $0-20$ & 0.3 & -0.2 \\
\hline \multirow[t]{2}{*}{ Chaetoceros sp. } & Mar 8, 1991 & 1 & $0.3 \pm 0.1$ & $0.3 \pm 0.1$ & - & $0-15$ & 0.1 & -0.1 \\
\hline & Mar 12, 1991 & 2 & $0.3 \pm 0.1$ & $0.1 \pm 0.1$ & - & $0-20$ & 0.2 & -0.2 \\
\hline \multirow[t]{2}{*}{ Thalassiosira rotula } & Mar 8, 1991 & 1 & $0.4 \pm 0.2$ & $0.5 \pm 0.2$ & - & $0-15$ & 0.2 & -1.0 \\
\hline & Mar 12, 1991 & 2 & $0.2 \pm 0.1$ & $0.2 \pm 0.1$ & - & $0-20$ & 0.1 & -0.5 \\
\hline Cyclotella caspia & Jul 25, 1990 & 1 & $2.9 \pm 0.4$ & $2.5 \pm 0.3$ & $-0.6 \pm 0.4$ & $0-15$ & 1.0 & -0.03 \\
\hline Cyclotella striata & Jul 25, 1990 & 1 & $0.6 \pm 0.2$ & $1.7 \pm 0.2$ & $-0.8 \pm 0.6$ & $0-15$ & 0.6 & -0.06 \\
\hline Ceratulina pelagica & Aug 2, 1990 & 1 & $0.2 \pm 0.1$ & $0.7+0.4$ & $-0.3 \pm 0.6^{\circ}$ & $0-15$ & 0.1 & $<-0.001$ \\
\hline \multirow[t]{4}{*}{ Rhodomonas lacustris } & Jul 25, 1990 & 1 & $3.0 \pm 0.8$ & $2.7 \pm 0.4$ & $-2.0+0.4$ & $0-15$ & 0.8 & -0.001 \\
\hline & Aug 2, 1990 & 1 & $0.7 \pm 0.2$ & $1.6 \pm 0.2$ & $-1.5 \pm 0.3$ & $0-15$ & 0.2 & $<-0.001$ \\
\hline & Mar 8, 1991 & 1 & $0.4 \pm 0.2$ & $0.2 \pm 0.1$ & - & $0-15$ & 0.1 & $<-0.001$ \\
\hline & Mar 12, 1991 & 2 & $0.3 \pm 0.1$ & $0.3 \pm 0.1$ & - & $0-20$ & 0.2 & -0.004 \\
\hline \multirow[t]{3}{*}{ Rhodomonas sp. } & Jul 25, 1990 & 1 & $1.8 \pm 0.7$ & $1.2 \pm 0.2$ & $-0.8 \pm 0.3$ & $0-15$ & 0.4 & -0.002 \\
\hline & Aug 2, 1990 & 1 & $0.6 \pm 0.2$ & $0.3 \pm 0.1$ & $-0.3 \pm 0.2$ & $0-15$ & 0.2 & $<-0.001$ \\
\hline & Mar 8, 1991 & 1 & $0.4 \pm 0.1$ & $0.6 \pm 0.1$ & - & $0-15$ & 0.2 & $<-0.001$ \\
\hline \multirow[t]{3}{*}{ Katodinium rotundatum } & Jul 25, 1990 & 1 & $2.6 \pm 0.3$ & $2.4 \pm 0.5$ & $-1.5 \pm 0.3$ & $0-15$ & 0.7 & $<-0.001$ \\
\hline & Aug 2, 1990 & 1 & $1.0 \pm 0.4$ & $0.5 \pm 0.2$ & $-0.4 \pm 0.3$ & $0-15$ & 0.2 & $<-0.001$ \\
\hline & Mar 8, 1991 & 1 & $0.8 \pm 0.4$ & $0.1 \pm 0.0$ & - & $0-15$ & 0.2 & $<-0.001$ \\
\hline \multirow[t]{2}{*}{ Gymnodinium spp. } & Mar 8, 1991 & 1 & $0.3 \pm 0.1$ & $0.1 \pm 0.1$ & - & $0-15$ & 0.1 & -0.004 \\
\hline & Mar 12, 1991 & 2 & $0.3 \pm 0.1$ & $0.1 \pm 0.1$ & - & $0-20$ & 0.2 & -0.006 \\
\hline \multirow[t]{3}{*}{ Ochromonas minima } & Aug 2, 1990 & 1 & $1.0 \pm 0.4$ & $0.9 \pm 0.5$ & $-0.9 \pm 0.2$ & $0-15$ & 0.4 & $<-0.001$ \\
\hline & Mar 8, 1991 & 1 & $1.2 \pm 0.2$ & $0.2 \pm 0.1$ & - & $0-15$ & 0.4 & $<-0.001$ \\
\hline & Mar 12, 1991 & 2 & $1.1 \pm 0.1$ & $0.6 \pm 0.1$ & - & $0-20$ & 0.7 & $<-0.001$ \\
\hline \multirow[t]{2}{*}{ Chrysochrom. spp. } & Aug 2, 1990 & 1 & $0.9 \pm 0.3$ & $1.0 \pm 0.2$ & $-0.8 \pm 0.3$ & $0-15$ & 0.2 & $<-0.001$ \\
\hline & Mar 8, 1991 & 1 & $0.8 \pm 0.3$ & $1.0 \pm 0.2$ & - & $0-15$ & 0.2 & $<-0.001$ \\
\hline Pseudopedinella sp. & Mar 8, 1991 & 1 & $0.8 \pm 0.2$ & $1.0 \pm 0.1$ & - & $0-15$ & 0.2 & -0.01 \\
\hline
\end{tabular}


microzooplankton grazing loss rates ranged from 0.1 to $2.0 \mathrm{~d}^{-1}$ with highest rates found in the plume region. Loss rates for non-diatoms were significantly higher than for diatoms (mean diatom $=0.4 \mathrm{~d}^{-1}$, mean nondiatom $=1.0 \mathrm{~d}^{-1}, t=2.6, \mathrm{p}=0.03, \mathrm{n}=14$ ). These differences were probably related more to size than to taxonomic affinity. All microzooplankton grazing loss rates for large $(>20 \mu \mathrm{m})$ or filamentous forms, which were all diatoms (i.e. Skeletonema costatum, Nitzschia pungens, Ceratulina pelagica), were never significantly different from zero $(\mathrm{p}>0.05)$. With 1 exception, all microzooplankton grazing losses were significantly different from zero for all small taxa $(<20 \mu \mathrm{m})$; the mean grazing loss rate was $1.0 \mathrm{~d}^{-1}$.

Microzooplankton grazing loss rates were also relatively high when compared to growth rates (Fig. 4; linear regression, $g=1.0 \mathrm{mz}+0.5$, where $g=$ growth rate and $m z=$ microzooplankton grazing rate, $\mathrm{R}^{2}=$ $0.51, \mathrm{p}=0.004, \mathrm{n}=14$ ), suggesting that microzooplankton grazing was one of the more important losses for phytoplankton during the summer. For small taxa $(<20 \mu \mathrm{m})$ microzooplankton grazing loss rates averaged $1.0 \mathrm{~d}^{-1}$, whereas growth rates averaged $1.4 \mathrm{~d}^{-1}$.

Unlike microzooplankton grazing loss rates which were measured in the upper $1 \mathrm{~m}$ of the water column, sedimentation loss rates were an integrative measure over the upper 15 or $20 \mathrm{~m}$. Sedimentation loss rates ranged from $<0.0001$ to $1.0 \mathrm{~d}^{-1}$ (Table 2). Sedimentation loss was primarily associated with diatoms (Fig. 5; mean rate $=0.25 \mathrm{~d}^{-1}$ ). The highest sedimentation rates were observed for the largest colonial diatoms (i.e. Thalassiosira rotula, Skeletonema costatum). The very low rates on Fig. 5 from Cruise 1 were for either lightly silicified, slow-growing diatoms (Ceratulina pelagica, Rhizosolenia fragilissima) or for fast-growing, small

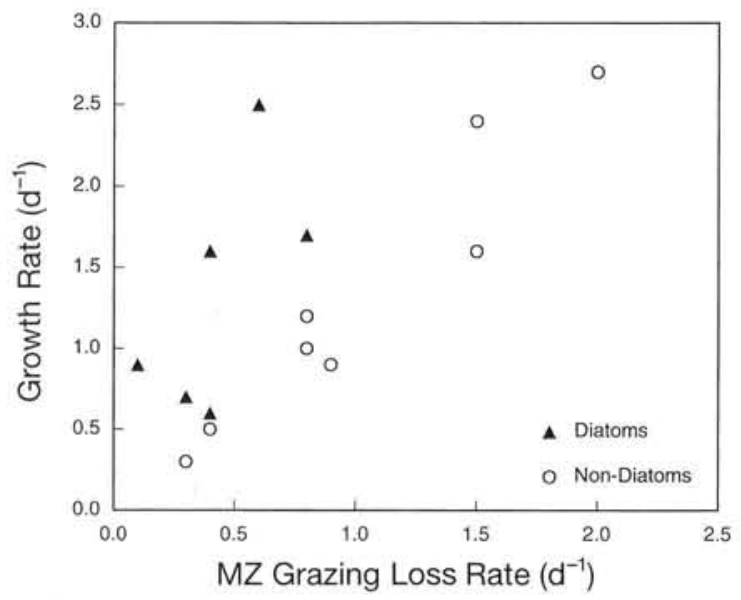

Fig. 4. Growth rates and microzooplankton (MZ) grazing loss rates for diatoms and non-diatoms from the July/August 1990 cruise. Growth and grazing rates were determined from dilution experiments

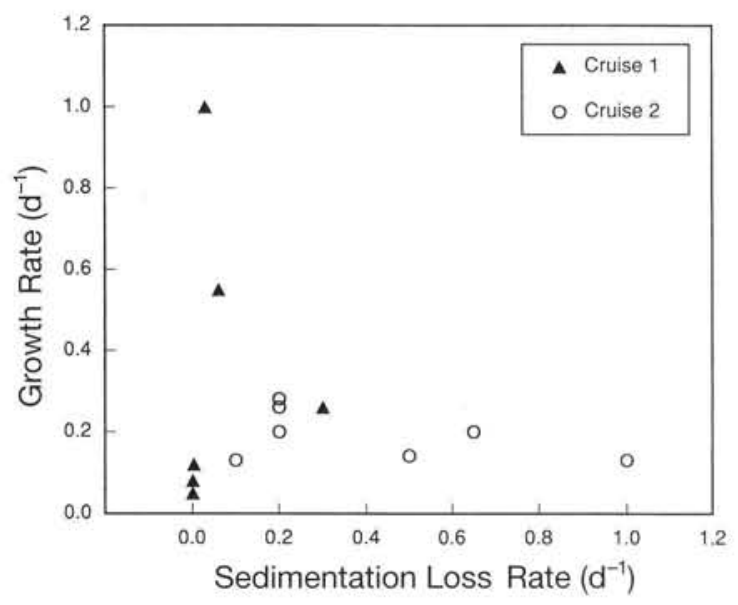

Fig. 5. Diatom growth and sedimentation loss rates from July/August 1990 (Cruise 1) and March 1991 (Cruise 2)

centric diatoms (Cyclotella spp.). Diatom sedimentation rates from the spring cruise were significantly higher (ca $6 \times$ ) than rates from the summer cruise (Fig. $5 ; t=2.6, \mathrm{p}<0.05$ ). From the spring cruise diatom sedimentation rates were approximately $2 \times$ integrated growth rates, whereas during the summer cruise diatom sedimentation rates were only $20 \%$ of integrated growth rates (Fig. 5). Similar patterns were noted for sinking rates of diatoms; high sinking rates were found for $S$. costatum ( 4 to $13 \mathrm{~m} \mathrm{~d}^{-1}$ ) and T. rotula $\left(>20 \mathrm{~m} \mathrm{~d}^{-1}\right)$ and much lower rates for C. pelagica, $R$. fragilissima $\left(<0.1 \mathrm{~m} \mathrm{~d}^{-1}\right)$, and small centrics $(0.2$ to $1.5 \mathrm{~m} \mathrm{~d}^{-1}$ ).

Sedimentation was not an important process for nondiatoms; the highest rate was $0.01 \mathrm{~d}^{-1}$, and the mean rate was only $0.001 \mathrm{~d}^{-1}$ (Table 2 ). Integrated growth rates for the same non-diatoms averaged $0.34 \mathrm{~d}^{-1}$. All sinking rates for non-diatoms were $<0.3 \mathrm{~m} \mathrm{~d}^{-1}$.

\section{DISCUSSION}

The growth rates measured in the plume region of the Mississippi River are some of the highest reported for marine phytoplankton (see review in Furnas 1990). Despite limited comparative data, particularly for microflagellates, several of our taxon-specific growth rates (Table 2) are close to or exceed the highest reported in situ rate and/or the maximal reported rate $\left(\mu_{\max }\right)$ under optimal culture conditions. For example, Katodinium rotundatum, a small dinoflagellate, has a $\mu_{\max }$ of $1.5 \mathrm{~d}^{-1}$ at $20^{\circ} \mathrm{C}$ (Throndsen 1976) and a maximal reported field growth rate of $1.0 \mathrm{~d}^{-1}$ (Owens et al. 1977). Our growth rate for $K$. rotundatum of $2.4 \mathrm{~d}^{-1}$ in the surface waters on July 25 is higher than both previous values (Table 2). The small microflagellate Ochromonas minima had a maximal in situ growth rate 
of $1.8 \mathrm{~d}^{-1}$ in the plume region on July 22 . This measured rate is higher than the previous $\mu_{\max }$ of $1.2 \mathrm{~d}^{-1}$ for this species which was reported at 25 to $28^{\circ} \mathrm{C}$ (Throndsen 1976). These very high rates were not limited to microflagellates, but were also noted for diatoms. $S$. costatum has a carbon-specific $\mu_{\max }$ of approximately $2.5 \mathrm{~d}^{-1}$ (Furnas 1982, Langdon 1988). In this study the highest growth rate for Skeletonema costatum was $2.0 \mathrm{~d}^{-1}$ (Table 2). Although we do not have comparative data, the small centric diatom Cyclotella caspia exhibited a growth rate of $2.9 \mathrm{~d}^{-1}$ (Table 2).

In a recent review of in situ growth rates, Furnas (1990) noted a dichotomy between diatom and nondiatom growth rates. While his review was primarily limited to readily identifiable and preserved species, Furnas noted that diatoms had higher mean and maximal in situ growth rates than non-diatoms; maximal rates for non-diatoms were approximately $2.1 \mathrm{~d}^{-1}$. An examination of $\mu_{\max }$ from laboratory cultures supported the same pattern.

Our work does not support this dichotomy in growth rates, particularly when microflagellates are considered. In fact, microflagellate growth rates $\left(\right.$ mean $=1.2 \mathrm{~d}^{-1}$ ) were slightly higher than diatom growth rates (mean $=$ $0.9 \mathrm{~d}^{-1}$ ) in the plume region, although these differences were not significant $(p=0.09)$. In the hypoxia region, diatom growth rates were significantly lower than rates for microflagellates ( $p<0.01$ ), most likely due to the limited availability of silicon (see discussion below). Also, the highest growth rate found in this study was $3.0 \mathrm{~d}^{-1}$ for the small cryptophyte, Rhodomonas lacustris. It is unlikely that diatoms would consistently have higher in situ growth rates and $\mu_{\max }$ values than all other taxa regardless of the resource scenario. Differences in $\mu_{\max }$ have obvious importance in the outcome of resource competition (Sell et al. 1984). It is difficult for us to believe that diatoms would always possess higher values. Moreover, the pattern noted by Furnas (1990) is not supported by studies on freshwater algae. In a review of maximal laboratory growth rates from freshwater phytoplankton, the average diatom rate $\left(1.1 \mathrm{~d}^{-1}\right)$ was less than the average for non-diatoms $\left(1.2 \mathrm{~d}^{-1}\right)$; the 6 highest rates were for nondiatoms (Reynolds 1984).

The dichotomy in $\mu_{\max }$ and in situ rates for diatoms and non-diatoms noted by Furnas (1990) possibly resulted from limited data and methodological considerations. The laboratory data on $\mu_{\max }$ for microflagellates reviewed by Furnas was limited to 5 studies with $50 \%$ of the data from 1 study. Culture conditions strongly influence $\mu_{\max }$, and more laboratory work is needed to establish $\mu_{\max }$ for microflagellates under a variety of growth conditions. Also, most in situ growth rates were measured with diffusion chambers, which may bias growth estimates for microflagellates. In this technique phytoplankton assemblages are enclosed in diffusion chambers for several days (usually 2 to $3 \mathrm{~d}$ ), after which growth rates are estimated by changes in abundance. Several aspects of this technique may be detrimental to the growth of microflagellates, including prefiltration of the inocula and long duration of the experiment. Microflagellates can be damaged during pre-filtration (Bloem \& Gilissen 1985, Goldman \& Dennett 1986) and they also are sensitive to containment (Venrick et al. 1975, Fahnenstiel \& Scavia 1987). We believe that future work in marine environments using a variety of techniques will not find a consistent dichotomy in growth rates. This premise is supported by recent work with a group-specific pigment labeling technique. Gieskes \& Kraay (1989) measured growth rates of diatoms, Prymnesiophyceae (flagellates) and Cyanobacteria in the Banda and Arafura Seas. They found that the range in growth rates of the 3 groups was relatively similar. Regional difference were noted in the maximal growth rates of all groups and no group consistently exhibited the highest growth rates.

Our high growth rates for microflagellates are further supported by the good agreement between ${ }^{14} \mathrm{C}$ and dilution estimates of growth $(p>0.05)$. Both techniques provided very high rates $\left(>2 \mathrm{~d}^{-1}\right)$ for several microflagellates (Table 2). Rarely in the past have species-specific growth rates been measured with 2 independent techniques (Furnas 1990). Because neither technique actually measures the intrinsic growth or cell division rate, this type of collaboration is needed and should be more common in future studies. It is clear that either technique can provide highly variable estimates of growth for a taxa on a given date (Table 2). Overall, dilution growth rates were significantly higher than ${ }^{14} \mathrm{C}$-based estimates for diatoms $(p=0.02)$. Although these rates were statistically significant, dilution growth rates were on average only $25 \%$ higher than ${ }^{14} \mathrm{C}$ estimates. Because significant differences were noted only for diatoms, they may be related to our cellular carbon estimates and their associated inaccuracies (Sicko-Goad et al. 1983).

Environmental conditions in the plume waters of the Mississippi River are favorable for growth of many species of phytoplankton. During the summer, nitrate concentrations ranged from 25 to $100 \mathrm{mmol} \mathrm{l}^{-1}$, and temperatures were approximately $30^{\circ} \mathrm{C}$. Given saturating light levels ( 25 to $50 \%$ of $I_{0}$ ) of a near-surface incubation, it is not surprising that many taxa were growing at or near $\mu_{\max }$. Because of limited data on in situ growth rates for many of the taxa reported in this investigation, the high growth rates from the plume region may be useful for assessing relative growth rates in other environments and for determining the role of environmental factors in controlling growth rates. 
The concentration of available nutrients plays an important role in controlling in situ growth rates in the study region. Over $50 \%$ of the variability in growth rates can be attributed to soluble nitrogen concentration alone. The Mississippi River is likely to be the source of nutrients to our entire study region; very high concentrations of all major dissolved nutrients are found at the mouth of the Mississippi River. Thus, nutrient concentrations in this region probably reflect supply rates. The strong nutrient control is not necessarily related to biological or chemical processes, but most likely to physical processes. The importance of physical mixing and dilution of the Mississippi River water as it moves onto the shelf can be demonstrated by the strong relationship between salinity and growth rate; over $40 \%$ of the variability in growth rates can be explained by salinity.

Silicon may be an important limiting nutrient in the northern Gulf of Mexico (Dortch \& Whitledge 1992) and other eutrophied regions (Conley et al. 1993). In the plume region of the Mississippi River, Dortch \& Whitledge (1992) concluded that silicon could limit phytoplankton production, based on an analysis of dissolved nutrient concentrations and an indicator of nitrogen deficiency. Silicon limitation in this region could have important implications for changes in phytoplankton species composition, fate of carbon, and intensity of hypoxia events. Our growth rates can be used to assess the degree of silicon limitation in the study region. Clearly, neither silicon nor any other nutrient was severely limiting growth in the surface waters at our plume stations, where diatom growth rates were high and comparable to microflagellate rates. In the hypoxia region where silicon limitation is most likely, diatom growth rates were significantly lower than non-diatom rates $(\mathrm{p}<0.01)$. Thus, it is likely that silicon was limiting to diatom growth in this region. Further evidence for silicon limitation can be found in the dissolved nutrient concentrations and ratios at stations in the hypoxia region. $\mathrm{Si}: \mathrm{N}$ ratios of $<1$ have been used to indicate possible Si limitation (Dortch \& Whitledge 1992). In the surface waters of the hypoxia region, silicon concentration were at or below detection level, and $\mathrm{Si}: \mathrm{N}$ ratios were less than or equal to 1 . This information, combined with our growth rate data, suggests that silicon was limiting to diatom growth in the hypoxia region.

Because diatom composition also changed from the plume to the hypoxia region, our growth rate data do not provide unequivocal support for the role of silicon. When evaluating the effects of nutrient supply and limitation on phytoplankton populations, changes in relative, not absolute, growth rates should be used. Any changes in species composition which might have produced differences in $\mu_{\max }$ would complicate our interpretation; nutrient-based competition outcomes are very sensitive to slight differences in $\mu_{\max }$ values (Sell et al. 1984).

One major objective of the NECOP program was to determine the fate of phytoplankton in the outfall region of the Mississippi River. Our data suggest that the fate of phytoplankton appeared to be primarily controlled by size and degree of silicification. For all small single cells $(<20 \mu \mathrm{m})$ microzooplankton grazing was an important loss, particularly for microflagellates, where microzooplankton grazing rates ranged from 40 to $214 \%$ of the growth rate with a mean of $82 \%$. For these same microflagellates, sedimentation rates were always $<1 \%$ of the growth rate; only in $33 \%$ of the cases were significant sedimentation rates measured. This relatively tight coupling between growth of microflagellates and grazing by microzooplankton suggests a very active microbial food web in both regions of the study, plume and hypoxia, similar to those reported elsewhere (Fenchel 1988, Hagström et al. 1988, Scavia \& Fahnenstiel 1988). Microzooplankton grazing was also important for small centric diatoms of the genus Cyclotella; however, unlike for small flagellates, significant sedimentation losses were also noted for these cells (Table 2).

Sedimentation was an important loss for many diatom species, and significant taxon-specific differences were noted. The larger colonial diatoms, such as Skeletonema costatum and Thalassiosira rotula, exhibited the highest sedimentation loss rates $(0.2$ to $1.0 \mathrm{~d}^{-1}$ ), whereas large, lightly silicified diatoms, such as Rhizosolenia fragilissima and Ceratulina pelagica, exhibited the lowest rates $\left(<0.01 \mathrm{~d}^{-1}\right)$. Significant taxon-specific differences were noted at all sampling locations; these differences were not easily attributed to factors such as physiological condition, density, size, life history, or shape (Smayda 1970, Walsby \& Reynolds 1981, Waite et al. 1992) due to our limited data and the integrative nature of the individual taxa. The taxaspecific sedimentation rates integrate many general (i.e. density, size, etc.) and specific (i.e. life history) factors; therefore, it is difficult to attribute differences in sedimentation loss rates to any one factor. For example, despite a limited range in growth rates during the spring cruise, sedimentation loss varied by a factor of 10 , suggesting that physiological control was not a predominant factor (Fig. 5). However, for almost all taxa, spring sedimentation rates were much higher and growth rates lower than summer values which suggests a possible link between growth rate and sedimentation loss rate.

The results from our study further highlight the importance of loss processes in controlling phytoplankton population abundance and seasonal succession in the northern Gulf of Mexico. Although signifi- 
cant differences were noted both within and among groups in terms of growth rates, larger and more distinct differences were noted for loss rates. These differences were not always easily predicted and strongly suggest that any future study on seasonal succession or factors controlling phytoplankton dynamics in the Gulf of Mexico should measure loss processes. The importance of loss processes in controlling phytoplankton population dynamics and seasonal succession have been noted from several studies in freshwater lakes which used similar taxon-specific measurements (Knoechel \& Kalff 1975, 1978, Crumpton \& Wetzel 1982).

Because our study is relatively unique, with measurements of both taxon-specific growth and loss rates for nano- and net phytoplankton, our data can provide some insights into the use of techniques that measure group-specific or ataxonomic rates just above the species level but below the community level (Gieskes \& Kraay 1989, McManus \& Ederington-Cantrell 1992, Goericke \& Welschmeyer 1993). For example, high performance liquid chromatography (HPLC) has been combined with radiolabeling techniques to determine the production and growth rates of specific groups such as diatoms, dinoflagellates, etc. by examining the specific activity in diagnostic pigments (Gieskes \& Kraay 1989). Pigments also have been measured in dilution experiments to provide group-specific determinations of growth and microzooplankton grazing loss rates (Strom \& Welschmeyer 1991, McManus \& EderingtonCantrell 1992). As pointed out by Furnas (1990) and Millie et al. (1993) these techniques have tremendous potential to both measure and provide insights into group-specific processes such as the importance of silicon to diatoms. However, these group-specific measurements will miss important taxon-specific differences that occur within each group and will provide only limited information about the group. Group-specific measurements, such as the labeling of ${ }^{14} \mathrm{C}$ into fucoxanthin, provides a weighted estimate of diatom growth rate which is a product of all the individual species growth rates and biomass. Without more information on the variance or distribution of the individual growth rates, the weighted estimate has limited value. As demonstrated by our study, species or taxon differences are significant and important to understanding successional patterns among phytoplankton. For example, growth rates for the 4 most abundant diatoms from the same plume sample varied from 0.1 to $1.0 \mathrm{~d}^{-1}$. Similar differences for both growth and loss rates for other closely related taxa (diatoms and flagellates) can be found in Table 2. Thus, without more information than a weighted estimate, one cannot assume that all taxa within a group have similar rates or that this weighted rate is representative of the most abundant taxon.
Acknowledgements. The authors thank J. Cavaletto for technical assistance, Dr Q. Dortch for critical assistance and advice, Dr M. Dagg for supplying samples for the microzooplankton grazing experiment, and Dr R. Knoechel and an anonymous reviewer for constructive comments on an earlier version of the manuscript. GLERL contribution 906 and CMS/USM contribution 174 .

\section{LITERATURE CITED}

Bloem, J., Gilissen, M.-J. B. B. (1988). Fixing nanoflagellates. Arch. Hydrobiol. Beih. Ergebn. Limnol. 31: 275-280

Campbell, L., Carpenter, E. J. (1986). Estimating the grazing pressure of heterotrophic nanoplankton on Synechococcus spp. using the sea water dilution and selective inhibitor techniques. Mar. Ecol. Prog. Ser. 33: 121-129

Carney, H. J., Fahnenstiel, G. L. (1987). Quantification of track and grain density autoradiography and evaluation of ${ }^{14} \mathrm{C}$ loss on preservation. J. Plankton Res. 9: 41-50

Carpenter, S. R., Frost, T. M., Kitchell, J. F., Kratz, T. K. (1993). Species dynamics and global environmental change: a perspective from ecosystem experiments. In: Kareiva, P. M., Kingsolver, J. G., Huey, R. B. (eds.) Biotic interactions and global change. Sinauer Assoc., Sunderland, MA

Conley, D. J., Schelske, C. L., Stoermer, E. F. (1993). Modification of the biogeochemical cycle of silica with eutrophication. Mar. Ecol. Prog. Ser. 101: 179-192

Crumpton, W. G., Wetzel, R. G. (1982). Effects of differential growth and mortality in the seasonal succession of phytoplankton populations in Lawrence Lake, Michigan. Ecology 63: 1729-1739

Dortch, Q., Whitledge, T. E. (1992). Does nitrogen or silicon limit phytoplankton production in the Mississippi River Plume and nearby regions? Cont. Shelf Res. 12: 1293-1309

Dozier, B. J., Richerson, P. (1975). An improved membrane filter method for the enumeration of phytoplankton. Verh. int. Verein. Limnol. 19: 1524-1529

Fahnenstiel, G. L., Scavia, D. (1987). Dynamics of Lake Michigan phytoplankton: primary production and growth. Can. J. Fish. Aquat. Sci. 44: 499-508

Fahnenstiel, G. L., Scavia, D., Lang G. A., Saylor J. H., Miller, G. S., Schwab, D. J. (1988). Impact of inertial period internal waves on fixed-depth primary production estimates. J. Plankton Res. 10: 77-87

Fenchel, T. (1988). Marine plankton food chains. A. Rev. Ecol. Syst. 19: 19-38

Furnas, M. J. (1982). Growth rates of summer nanoplankton in lower Narragansett Bay, Rhode Island, USA. Mar. Biol. 70: 105-115

Furnas, M. J. (1990). In situ growth rates of marine phytoplankton: approaches to measurement, community and species growth rates. J. Plankton Res. 12: 1117-1151

Gieskes, W. W. C., Kraay, G. W. (1989). Estimating the carbon-specific growth rate of the major algal species groups in eastern Indonesian waters by the ${ }^{14} \mathrm{C}$ labeling of taxon-specific carotenoids. Deep Sea Res. 36: 1127-1139

Goericke, R., Welschmeyer, N. A. (1993). The carotenoidlabeling method: measuring specific rates of carotenoid synthesis in natural phytoplankton communities. Mar. Ecol. Prog. Ser. 98: 157-171

Goldman, J. C., Dennett, M. R. (1985). Susceptibility of some marine phytoplankton species to cell breakage during filtration and post-filtration rinsing. J. exp. mar. Biol. Ecol. 86: $47-58$

Guillard, R. R. L., Kilham, P. (1977). The ecology of marine planktonic diatoms, In: Werner, D. (ed.) The biology of 
diatoms. Univ, California Press, Berkeley, p. 372-469

Hagström, A., Azam, F., Andersson, A., Wikner, J., Rassoulzadegan, F. (1988). Microbial loop in an oligotrophic pelagic marine ecosystem: possible roles of cyanobacteria and nanoflagellates in the organic fluxes. Mar. Ecol. Prog. Ser. 49: 171-178

Kalff, J., Knoechel, R. (1978). Phytoplankton and their dynamics in oligotrophic and eutrophic lakes. A. Rev. Ecol. Syst. 9: 475-495

Knauer, G. A., Martin, J. H., Bruland, K. W. (1979). Fluxes of particulate carbon, nitrogen, and phosphorus in the upper water column of the northeast Pacific. Deep Sea Res. 26: 97-108

Knauer, G. A., Redalje, D. G., Harrison, W. G., Karl, D. M. (1990). New production at the VERTEX time-series site. Deep Sea Res. 37: 1121-1134

Knoechel, R., Kalff, J. (1975). Algal sedimentation: the cause of a diatom-blue-green succession. Verh. int. Verein. Limnol. 19: 745-754

Knoechel, R., Kalff, J. (1976). Track autoradiography, a method for the determination of phytoplankton species productivity. Limnol. Oceanogr. 21: 590-596

Knoechel, R., Kalff, J. (1978). An in situ study of the productivity and population dynamics of five freshwater planktonic diatom species. Limnol. Oceanogr. 23: 195-218

Landry, M. R., Haas, L. W., Fagerness, V. L. (1984). Dynamics of microbial plankton communities: experiments in Kaneohe Bay, Hawaii. Mar. Ecol. Prog. Ser. 16: 127-133

Landry, M. R., Hassett, R. P. (1982). Estimating the grazing impact of marine micro-zooplankton. Mar. Biol. 67: 283-288

Langdon, C. (1988). On the causes of interspecific differences in the growth-irradiance relationship for phytoplankton. II. A general review. J. Plankton Res. 10: 1291-1312

Li, W. K. W. (1984). Microbial uptake of radiolabeled substrates: estimates of growth rates from time course measurements. Appl. environ. Microbiol. 47: 184-192

Li, W. K. W., Goldman, J. C. (1986). Exponential growth rates of phytoplankton calculated from ${ }^{14} \mathrm{C}$ uptake rates: a clarification. J. Plankton Res. 8: 1177-1181

Lohrenz, S. E., Dagg, M. J., Whitledge, T. E. (1990). Enhanced primary production at the plume/oceanic interface of the Mississippi River. Cont. Shelf Res. 10: 639-664

Lohrenz, S. E., Wiesenburg, D. A., Rein, C. R., Arnone, R. A., Taylor, C. D., Knauer, G. A., Knap, A. H. (1992). A comparison of in situ and simulated in situ methods for estimating oceanic primary production. J. Plankton Res. 14: 201-221

McManus, G. B., Ederington-Cantrell, M. C. (1992). Phytoplankton pigments and growth rates, and microzooplankton grazing in a large temperate estuary. Mar. Ecol. Prog. Ser. 87: 77-85

Millie, D. F., Paerl, H. W., Hurley, J. P. (1993). Microalgal pigment assessments using high-performance liquid chromatography: a synopsis of organismal and ecological applications. Can. J. Fish. Aquat. Sci. 50: 2513-2527

Moody, C. L. (1967). Gulf of Mexico distributive provinces. Am. Ass. Petrol. Geol. Bull. 51: 179-199

Owens, O. V. H., Dresler, P., Crawford, C. C., Taylor, M. A., Seliger, H. H. (1977). Phytoplankton cages for the measurement on in situ growth rates of mixed natural phytoplankton. Chesapeake Sci. 18: 325-333

Raymont, J. E. G. (1980). Plankton and productivity in the oceans: Vol. 1, Phytoplankton (2). Pergamon Press, Oxford Reynolds, C. S. (1984). The ecology of freshwater phytoplankton. Cambridge Univ. Press, Cambridge

Riley, G. A. (1937). The significance of the Mississippi River drainage for biological conditions in the northern Gulf of Mexico. J. mar. Res. 1: 60-74

Scavia, D., Fahnenstiel, G. L. (1988). From fish to picoplankton: complex interactions in the Great Lakes, In: Carpenter, S. R. (ed.) Complex interactions in lake communities. Springer-Verlag, New York, p. 85-97

Sell, D. W., Carney, H. J., Fahnenstiel, G. L. (1984). Inferring competition between natural phytoplankton populations: the Lake Michigan example re-examined. Ecology 65: 325-328

Sicko-Goad, L. M., Schelske, C. L., Stoermer, E. F. (1984). Estimation of intracellular carbon and silica content of diatoms from natural assemblages using morphometric techniques. Limnol. Oceanogr. 29: 1170-1178

Sklar, F. H., Turner, R. E. (1981). Characteristics of phytoplankton production off Barataria Bay in an area influenced by the Mississippi River. Contr. mar. Sci. 24: 93-106

Smayda, T. J. (1970). The suspension and sinking of phytoplankton in the sea. Oceanogr. mar. Biol. A. Rev. 8: $353-414$

Smayda, T. J. (1980). Phytoplankton species succession. In: Morris, I. (ed.) The physiological ecology of phytoplankton. Univ. California Press, Berkeley, p. 493-570

Strathman, R. R. (1967). Estimating the organic carbon content of phytoplankton from cell volume or plasma volume. Limnol. Oceanogr. 12: 411-418

Strom, S. L., Welschmeyer, N. A. (1991). Pigment-specific rates of phytoplankton growth and microzooplankton grazing in the open subarctic Pacific Ocean. Limnol. Oceanogr. 36: 50-63

Thomas, W. H., Simmons, E. G. (1960). Phytoplankton production in the Mississippi Delta. In: Shepard, F. (ed.) Recent sediments, Northwest Gulf of Mexico. Am. Assoc. Petrol., Tulsa, p. 103-116

Throndsen, J. (1976). Occurrence and productivity of small marine flagellates. Norw. J. Bot. 23: 269-293

Turner, R. E., Rabalais, N. N. (1991). Changes in Mississippi River water quality this century. BioSci. 41: 140-147

Venrick, E. L., Beers, J. R., Heibokel, J. F. (1975). Possible consequences of containing microplankton for physiological rate measurements. J. exp. mar. Biol. Ecol. 26: 55-76

Verity, P. G., Robertson, C. Y., Tronzo, C. R., Andrews, M. G., Nelson, J. R., Sieracki, M. E. (1992). Relationships between cell volume and the carbon and nitrogen content of marine photosynthetic nanoplankton. Limnol. Oceanogr. 37: $1434-1446$

Waite, A. M., Thompson, P. A., Harrison, P. J. (1992). Does energy control the sinking rates of marine diatoms? Limnol. Oceanogr. 37: 468-477

Walsby, A. E., Reynolds, C. S. (1980). Sinking and floating. In: Morris, I. (ed.) The physiological ecology of phytoplankton. Blackwell Scientific Publ., Oxford, p. 371-412

Welschmeyer, N. A., Lorenzen, C. J. (1984). Carbon-14 labeling of phytoplankton carbon and chlorophyll a carbon: determination of specific growth rates. Limnol. Oceanogr. 29: $135-145$

Wood, A. M., Leatham, T. (1992). The species concept in phytoplankton ecology. J. Phycol. 28: 723-729

Manuscript first received: May 22, 1994

Revised version accepted: September 28, 1994
This article was presented by B. \& E. Sherr (Senior Editorial Advisors), Corvallis, Oregon, USA 